\title{
Notes on the Mollusca from Site 41DT59, Cooper Lake, Delta County, Texas
}

Jesse Todd

MA Counslting

Follow this and additional works at: https://scholarworks.sfasu.edu/ita

Part of the American Material Culture Commons, Archaeological Anthropology Commons, Environmental Studies Commons, Other American Studies Commons, Other Arts and Humanities Commons, Other History of Art, Architecture, and Archaeology Commons, and the United States History Commons

Tell us how this article helped you.

This Article is brought to you for free and open access by the Center for Regional Heritage Research at SFA ScholarWorks. It has been accepted for inclusion in Index of Texas Archaeology: Open Access Gray Literature from the Lone Star State by an authorized editor of SFA ScholarWorks. For more information, please contact cdsscholarworks@sfasu.edu. 
Notes on the Mollusca from Site 41DT59, Cooper Lake, Delta County, Texas

Creative Commons License

(c) $)(1)$ (9)

This work is licensed under a Creative Commons Attribution-NonCommercial 4.0 International License 


\title{
NOTES ON THE MOLLUSCA FROM SITE 41DT59, COOPER LAKE, DELTA COUNTY, TEXAS
}

\author{
Jesse Todd, \\ MA Consulting
}

This paper focuses on the information about the mollusca from site 41DT59. The author takes the information from Dr. Fullington, the noted malacologist, and illustrates how the archeologist can take the information and apply it to site analysis. This information derived from the analysis mainly supports what the authors have concluded about site 41DT59, but does discuss material not covered in the original text. The analysis is divided into two sections. The information derived from the gastropods is discussed first, and the information derived from the mussels second.

\section{The Gastropods}

In their interpretation of the soils for site 41DT59, Shanabrook, Hunt, and Cliff (1955:F-7) state that they believe the sediments from Unit 25 were probably alluvial floodplain deposits. Based on the gastropod shells found in the excavation, they are correct. The species Anguispira strongylodes was recovered from the upper $10 \mathrm{~cm}$, species Rabdotus dealbatus, Gastropta contracta, Strobilops texasiana, Hawaiia minuscula, Zontoides arboreus, and Glyphyalinia indentata were recovered from the $10-20 \mathrm{~cm}$ level, and species Gastrocopta contracta, Glyphyalinia indentata, Rabdotus dealbatus, Strobilops texasiana, and Mesodon thyroidus were recovered from $20-30 \mathrm{~cm}$ below datum (Fullington 1995:H-3). Fullington (1995:H-3) states that A. strongylodes prefers exposed knolls surrounded by trees or shrubs. The remaining gastropod fauna, however, prefer an oak-savannah environment that may be slightly moister than that for $A$. strongylodes.

All of the species in Level 2 can be found on floodplains in oak-savannah environments. Both $G$. indentata and $S$. texasiana can be found under leaves and rotting logs in moist areas in a floodplain, but $S$. texasiana prefers to be adjacent to streams or water. $G$. contracta prefers to be on rocks adjacent to the floodplain, although it can be found in the floodplain. H. minuscula lives under rocks and logs on a floodplain. Z. arboreus is always associated with trees, and $R$. dealbatus 
prefers mixed, drier grasslands and woods, even though it can be found on floodplains where there is standing water (Fullington and Pratt 1974).

Level 3 contained all of the gastropods in Level 2, which still indicates a floodplain, except for $H$. minuscula and $Z$. arboreus and contained M. thyroidus which Level 2 did not. M. thyroidus prefers mixed, drier grassland and woods similar to $R$. dealbatus. There may have been a grassier and drier environment during Level 3 times than Level 2 times.

\section{The Mussels}

Cliff and others (1995:100) list the species and percentages of the identified species in Table 1. Current scientific name are used instead of those used in 1995.

As is shown in Table 1, P. purpuratus is the most common mussel present in the sample. A. plicata is the second most common mussel present, but this is true only if one looks at the fragments. If one looks at the number of umbos/hinges re- covered from the site, P. purpuratus is still the most common mussel with 18 umbos/hinges present of 36 , or 50 percent. The next most common mussel represented by the umbos/hinges is L. hydiana with seven umbos/hinges $(18 \%$ of the sample) with $A$. plicata being represented by only one umbo ( $3 \%$ of the sample). Fullington (1995:H-3) stated that the site inhabitants use of $P$. purpuratus was unusual because $A$. plicata is usually the

Table 1. Common Name, Scientific Name, and Percentage of Fragments from Site $41 \mathrm{DT59.}$

\begin{tabular}{|l|l|r|r||}
\hline \multicolumn{1}{|c|}{ Common Name } & \multicolumn{1}{|c|}{ Scientific Name } & \multicolumn{1}{c|}{$\begin{array}{c}\text { Number of } \\
\text { Fragments }\end{array}$} & Percentage \\
\hline \hline Bluefer & Potamilus purpuratus & 52 & 54.2 \\
\hline Threeridge & Amblema plicata & 17 & 17.7 \\
\hline Louisiana Fatmucket & Lampsilis hydiana & 12 & 12.5 \\
\hline Pink Papershell & Potamilus ohioensis & 5 & 5.2 \\
\hline Yellow Sandshell & Lampsilis teres & 5 & 5.2 \\
\hline Texas Fatmucket & Lampsilis bracteata & 2 & 2.1 \\
\hline Mapleleaf & Quadrula quadrula & 2 & 2.1 \\
\hline Washboard & Megalonaias nervosa & 1 & 1.0 \\
\hline \hline
\end{tabular}


dominant food mussel found on prehistoric Native American sites.

By looking at the scatter of fragments, there were probably four $A$. plicata shells recovered from the site. Four is the MNI for $L$. hydiana based on the valve/umbo count also, meaning that the two species are about even in their popularity at the site. It appears that the three major mussel species eaten or used by the site inhabitants were $P$. purpuratus, $A$. plicata, and $L$. hydiana.

Because six of the eight species of mussels recovered from the site inhabit deeper streams or river waters (Cliff et al. 1995:100), they may have been gathered in the summer or fall when the water was low. The mussels such as $L$. teres which inhabit shallow water could have been gathered at any time. It is interesting that there were only two fragments of $Q$. quadrula and one fragment of $M$. nervosa recovered. $Q$. quadrula inhabits shallow water, oxygen rich riffles and runs (Howell et al. 1996:125), but M. nervosa inhabits deep water and suggests again that these mussels were gathered when the water was low.

Cliff and others (1995:52) suggest that the southeastern area of the site contained a kitchen midden and was not a primary occupational area based on the bone, shell and charcoal recovered from Unit 25. This conclusion is supported by the amount of shell recovered from Unit 25 . It contained 32 percent of the shell recovered from the site by itself. In addition, the mussels collected from Unit 25 show the greatest diversity of any other unit of the site.
Of the shell collected from 41DT59, 11 percent was burned. This percentage appears high to me. Ethnographic accounts and experiments suggest that roasting or boiling the mussels was the fastest way of cooking them [Henshilwood et al (1994:107); Parmalee and Klippell (1974:421); Waselkov (1987:169)]. The shell being burned, however, does not necessarily mean that it was intentional. It merely could have been incorporated into a fire accidentally.

It appears that the use of mussels increased over time at 41DT59, just like the use of other animals. Although mussels were not a major subsistence base, their importance can not be overlooked. For one thing, the amount of energy return for gathering time is greater. Brown (1988: 229), in his discussion of the subsistence practices of the prehistoric inhabitants of what is now Aquilla Lake, stated that mussels may have been an important source of calcium. Lintz (1996:T-14) pointed out that mussels recovered from two Early Archaic sites in the Concho River Terraces in Tom Green County provided fat and vitamin $\mathrm{A}$ as well as calcium.

One interesting aspect of mussels that has not been utilized much is their use to determine what fish were present in the stream that the mussels were recovered from. Since different mussel species may use the same fish for hosts for their glochidia, there has been no attempt to specify which fish were hosts to which mussel. Although no fish bones were identified at 41DT59, fish recovered from the Spike site (41DT16) included bowfin, 
catfish, drum, gar, and sunfish (Yates 1993:23). These fish could have been utilized for food at 41DT59 and other possibilities include white bass, rock bass, largemouth bass, bluegill, warmouth, white crappie, black crappie, and yellow perch. Other fish include northern pike, pumpkinseed, and sauger (Howells et al. 1996).

\section{Conclusions}

It appears that Shanabrook, Hunt, and Cliff's conclusion about Unit 25 is correct based on the gastropods present. Unit 25 was probably within a midden also based on the percentage of shell fragments present. The amount of burned shell seems high, especially when roasting was probably the most common form of cooking mussels. The mussels were probably gathered when the Sulphur River was low. In addition, potential fish species that might be found in the Sulphur River may be identified by which fish were used as hosts by the mussels' glochidia. Based on the locations of shell fragments and number of umbos/hinges present, the percentage of fragments may yield a false picture of the dominance of a species present at a site. Both $A$. plicata and $L$. hydiana are probably represented equally in the archeological record instead of $A$. plicata being more common as the percentages of shell fragments indicate.

\section{References Cited}

Brown, David O.

1988 Prehistoric Subsistence Strategies in Northeastern Central Texas. Bulletin of the Texas Archeological Society 59:201-244.

Cliff, Maynard B., Melissa Green, Steven H. Hunt, and David Shanabrook 1995 Archeological Test Excavations at Two Prehistoric Sites (41DT59 and 41DT247) at Cooper Lake, Delta County, Texas. Miscellaneous Reports of Investigations No. 90:49-198. Geo-

Marine, Inc., Plano.

Fullington, Richard W. 1995 Appendix H: Molluscan Remains
Recovered from Site 41DT59, Cooper Lake, Texas. In: Archeological Test Excavations at Two Prehistoric Sites (41DT59 and 41DT247) at Cooper Lake, Delta County, Texas, by Maynard B. Cliff, Melissa M. Green, Steven H. Hunt, and David Shanabrook. Miscellaneous Reports of Investigations No. 90:H1-H7 GeoMarine, Inc., Plano.

Fullington, Richard W., and William Lloyd Pratt, Jr.

1974 The "Helicinidae, Carychidiidae, Achatinidae, Bradybaenidae, Bulimulidae, Cionellidae, Haplotrematidae, Helicidae, 
Oreohelicidae, Spiraxidea, Streptaxidae, Stropolopsidae, Thysanophoridae, Valloniidae' (Gastropoda) in Texas. The Aquatic and Land Mollusca of Texas Bulletin 1 (Part 3). Dallas Museum of Natural History.

Henshilwood, Christopher, Peter Nilssen, and John Parkington

1994 Mussel Drying and Food Storage in the Late Holocene, SW Cape, South Africa. Journal of Field Archaeology 21:103-109.

Howells, Robert G., Raymond W. Neck, and Harold D. Murray 1996 Freshwater Mussels of Texas. Texas

Parks and Wildlife Department, Inland Fisheries Division, Austin.

Lintz, Christopher

1996 Appendix T: Dietary Data of Mussel

Shell Assemblages. In: Early Archaic Use of the Concho River Terraces: Cultural Resource Investigations at $41 T G 307$ and 41TG309, Tom Green County, San Angelo, Texas, by J. Michael Quigg, Jay Peck, Christopher Lintz, Abby C. Treece, Charles D. Frederick, Roman Clem, G. Lain Ellis, Paul Schuchert, and James T. Abbott, pp. T1 - T19. Technical Report 11058. TRC Mariah Associates, Inc., Austin.

Parmalee, Paul W., and Walter E. Klippell 1974 Freshwater Mussels as a Prehistoric

Food Source. American Antiquity 39(3):421-434.
Shanabrook, David, Steven M. Hunt, and Maynard B. Cliff

1995 Appendix F: Test Unit and Backhoe Trench Profile Descriptions, Sites 41DT59 and 41DT427, Cooper Lake, Texas. In: Archeological Test Excavations at Two Prehistoric Sites (41DT59 and 41DT427) at Cooper Lake, Delta County, Texas, by Maynard B. Cliff, Melissa M. Green, Steven M. Hunt, and David Shanabrook. Miscellaneous Report of Investigations No. 90:F1-F15. GeoMarine, Inc., Plano.

Waselkov, Gregory A.

1987 Shellfish Gathering and Shell Midden Archaeology. In: Advances in Archaeological Method and Theory, Volume 10, by Michael B. Schiffer (editor), pp. 93-210. Academic Press, New York.

Yates, Bonnie C.

1993 Appendix E: Zooarcheology of Four Woodland/Caddoan Sites at Cooper Lake. In: Excavations at the Tick, Spike, Johns Creek, and Peerless Bottom Sites, Cooper Lake Project, Delta and Hopkins Counties, Texas, by Ross C. Fields, Eloise F. Gadus, L. Wayne Klement, C. Britt Bousman, and Jerrilyn B. McLerran, pp. 310335. Reports of Investigations No. 91. Prewitt and Associates, Inc., Austin. 